\title{
Civilisation, Protection, Restitution: A Critical History of International Cultural Heritage Law in the 19th and 2oth Century
}

\author{
Sebastian M. Spitra \\ Department of Legal and Constitutional History, Faculty of Law, University \\ of Vienna, Vienna, Austria \\ sebastian.spitra@univie.ac.at
}

Received: 31 March 2019 | Revised: o9 March 2020 | Accepted: 13 June 2020 | Published online: 28 October 2020

\begin{abstract}
This article provides a new narrative for the history of cultural heritage law and seeks to contribute to current legal debates about the restitution of cultural objects. The modern protection laws for cultural objects in domestic and international law evolved in the 19th and 2oth century. The article makes three new arguments regarding the emergence of this legal regime. First, 'civilisation' was a main concept and colonialism an integral part of the international legal system during the evolution of the regime. The Eurocentric concept of civilisation has so far been an ignored catalyst for the international development of cultural heritage norms. Second, different states and actors used cultural heritage laws and their inherent connection to the concept of civilisation for different purposes. Third, the international legal system of cultural heritage partly still reflects its colonial roots. The current restitution discussions are an outcome of this ongoing problematic legal constellation.
\end{abstract}

\section{Keywords}

cultural heritage - colonialism - restitution - third world approaches to international law (TWAIL) - UNESCO - cultural property protection 
'Civilisation' was an integral and major concept of international law in the 19th and early 20 th century. ${ }^{1}$ It was an attribute taken from history and other disciplines to characterise entities of international law and determine their membership to the international community. ${ }^{2}$ Only civilised states that fulfilled the standard were allowed to be full members of the family of nations. ${ }^{3}$ During this era, also modern protection laws for cultural objects in domestic and international law evolved.

The aim of this article is to provide a new narrative for the history of the protection of cultural heritage. Such critical historiography shall revise the inherent politics of the often repeated, traditionally Eurocentric progress narrative to unveil the unjust structures of the past and their traces up to the present. The continuing discussions about the restitution of cultural heritage that has been 'translocated'4 during colonial times demand a fresh, critical and systemic inquiry into the broader history and historiography of this field.

The notions of 'protection', 'cultural heritage' or 'cultural property' itself are historical concepts and evolved in certain theoretical and political contexts. ${ }^{5}$ However, the scope and limitation of this article do not allow capturing all subtleties and complexities of the colonial contexts. It is necessary to make use of representative examples and to simplify some arguments, but further references are included in the footnotes to flag important debates or problematic issues.

The new approach of this article is to examine the role of the standard of civilisation in international law for the development of cultural heritage

1 Notions, such as 'civilisation', 'civilised', 'standard of civilisation' or the German 'Kultur', 'Kulturstaat', 'Kulturstandard', are used in this article solely analytical and not affirmatively. In the following, these notions will be reproduced without quotation marks for an easier reading.

2 An important work was Guizot, François. Histoire Générale de la Civilisation en Europe (Paris: Pichon et Didier, 1828); see also Steiger, Heinhard. 'Völkerrecht', in Geschichtliche Grundbegriffe, Vol. 7, eds. Otto Brunner, Werner Conze and Reinhart Koselleck (Stuttgart: Klett-Cotta, 1992), 97-140.

3 Anghie, Antony. 'Finding the Peripheries: Sovereignty and Colonialism in NineteenthCentury International Law'. Harvard International Law Journal 40(1) (1999), 1-80.

4 Savoy, Bénédicte. Die Provenienz der Kultur. Von der Trauer des Verlusts zum universalen Menschheitserbe (Berlin: Matthes \& Seitz, 2018).

5 For this argument, see, e.g., Prott, Lyndel V. and Patrick J. O'Keefe. "Cultural Heritage' or 'Cultural Property'?'. International Journal of Cultural Property 1(2) (1992), 307-320; Spitra, Sebastian M. Die Verwaltung von Kultur im Völkerrecht. Eine postkoloniale Geschichte (Baden-Baden: Nomos, forthcoming 2020). 
protection laws. The text proceeds by first, arguing based on three examples from international law that the concept of civilisation played a crucial role in the formation of cultural heritage norms that has been neglected so far. Second, it discusses how various actors used cultural heritage laws in different ways and how these norms fulfilled different purposes within the legal discourse of civilisation. Last, the article argues that today's discussions on returning cultural objects are not new but rather a reinvigoration of the decolonisation movement as seen in the restitution debates at the UN General Assembly in the 1970s, which had been stagnated until the last few years.

2

\section{The Neglected Role of 'Civilisation' in the History of International Cultural Heritage Law}

This section identifies different examples in which the concept of civilisation manifested itself in international cultural heritage law. Several historic studies have already focused on the significance of the civilisation concept for international law in recent years. ${ }^{6}$ Many fields of international law accordingly have revisited their founding narratives, ${ }^{7}$ but such a critical reassessment is still pending for international cultural heritage law. Histories of international cultural heritage law tend to treat only the pre-history of legal instruments and not broader contexts of the discipline. Consequently, this article focuses on the neglected influences of the concept of civilisation on the development of cultural heritage laws. Nevertheless, not all colonial and imperial encounters in the history of international cultural heritage law were based on the patterns described in this text. Colonised peoples similarly had impact on the

6 Shahabuddin, Mohammad. 'The 'Standard of Civilization' in International Law: Intellectual Perspectives from Pre-War Japan'. Leiden Journal of International Law 32(1) (2018), 13-32; Becker Lorca, Arnulf. Mestizo International Law. A Global Intellectual History 1842-1933 (Cambridge: Cambridge University Press, 2014); Obregón, Liliana. 'The Civilized and the Uncivilized', in The Oxford Handbook of the History of International Law, eds. Bardo Fassbender and Anne Peters (Oxford: Oxford University Press, 2012), 917-939; Pauka, Marc. Kultur, Fortschritt und Reziprozität. Die Begriffsgeschichte des zivilisierten Staates im Völkerrecht (Baden-Baden: Nomos Verlagsgesellschaft, 2012); Anghie, Antony. Imperialism, Sovereignty and the Making of International Law (Cambridge: Cambridge University Press, 2005); Gong, Gerrit W. The Standard of 'Civilisation' in International Society (Oxford: Oxford University Press, 1984).

7 See, e.g., Miles, Kate. The Origins of International Investment Law. Empire, Environment and the Safeguarding of Capital (Cambridge: Cambridge University Press, 2013). 
colonisers, their laws and culture. ${ }^{8}$ Their contribution to this system deserves further research.

The historic understanding of the concept of civilisation in international law is best documented in the most widely used English and German international law textbooks at the end of the long 19 th century. $^{9}$ One representative example is the standard treatise of the German law professor Franz von Liszt. ${ }^{10}$ He already described on the first page the structure of international law and the role of the standard of civilisation:

International Law $[\ldots]$ contains the legal rules that determine the rights and duties of the states that belong to the community of civilised states. $[\ldots]$ The community of the civilised states is delimited by the common shared convictions of law and the common culture and interests. ${ }^{11}$

The quote indicates that a state or legal entity has to be part of the community of civilised states (Kulturstaaten) in order to benefit from international legal rights. Liszt emphasised that a common culture and interests, which form the basis for the membership in this community, hold the community of civilised states together.

Another example is the authoritative English textbook of public international law written by the German émigré and legal positivist Lassa Francis Oppenheim..$^{12}$ He gave a definition comparable to Liszt's and only included civilised states in the legal sphere of international law: 'Law of Nations or International Law is the name for the body of customary and conventional rules which are considered legally binding by civilised States in their intercourse with each other.13 Oppenheim listed in his textbook the civilised states

8 See, e.g., Schwartz, Bill. The White Man's World (Oxford: Oxford University Press, 2011).

9 Although international law always refers to a shared and sometimes universal understanding of the discipline, there are national differences, see, e.g., Roberts, Anthea. Is International Law International? (Oxford: Oxford University Press, 2017).

10 Hermann, Florian. Das Standardwerk. Franz von Liszt und das Völkerrecht (Baden-Baden: Nomos, 2001).

11 Liszt, Franz von. Das Völkerrecht systematisch dargestellt (Berlin: Verlag von O. Haering, 1898), 1-4 (translation by the author).

12 Schmoeckel, Mathias. 'The Internationalist as a Scientist and Herald: Lassa Oppenheim'. European Journal of International Law 11(3) (2000), 699-712.

13 Oppenheim, Lassa Francis Lawrence. International Law. A Treatise, Vol. 1 (London: Longmans, Green, and Co., 1905), 1. 
of his time and only counted, for instance, the Republic of Liberia as full member of the family of nations on the continent of Africa. ${ }^{14}$

These doctrinal explanations certainly did not reflect all subtleties of the colonial and imperial encounters on the ground; however, they present the intellectual framework and the legal justifications used in these contexts that also became important for shaping cultural heritage norms. ${ }^{15}$ Considering this problematic legacy of international law, it is surprising that these colonial and imperial contexts are hardly addressed in the histories of cultural heritage in international law. ${ }^{16}$ This section intends to illustrate how the concept of civilisation has shaped the discourse on cultural heritage in international law based on three examples: the hegemonic patterns of cultural co-operations, the ambivalent implications of the 'civilising' narrative for the laws of war and the colonial bias of codification projects in the interwar period.

\subsection{Defining Hegemonic Interests: Cultural Co-operations in International Law}

The concept of civilisation was an important factor in organising international cultural co-operations, which was also acknowledged by international legal doctrine. The community of civilised states constituted for many international lawyers also a dogmatic construct carrying its own interests. The legal theories of 'common interests' and the 'solidarity of interests' built the background against which a common responsibility of civilised states for the cultural heritage in international law developed. ${ }^{17}$ Those interests marked a point of origin and legitimised international regulations in the 19th and early 20 th century. ${ }^{18}$ Several influential international law textbooks focused on this 'community of interests' with regard to cultural matters.

14 Oppenheim, Lassa Francis Lawrence. International Law. A Treatise, Vol. 1 (London: Longmans, Green, and Co., 2nd ed., 1912), 164.

15 For such approaches, see, e.g., Benton, Lauren and Lisa Ford. Rage for Order. The British Empire and the Origins of International Law, 1800-1850 (Cambridge: Harvard University Press, 2016); Rajagopal, Balakrishnan. International Law from below. Development, Social Movements and Third World Resistance (Cambridge: Cambridge University Press, 2003).

16 For some exceptions, see, e.g., Gaudenzi, Bianca and Astrid Swenson. 'Looted Art and Restitution in the Twentieth Century - Towards a Global Perspective'. Journal of Contemporary History 52(3) (2017), 491-518; Greenfield, Jeanette. The Return of Cultural Treasures (Cambridge: Cambridge University Press, 2007); Vrdoljak, Ana Filipa. International Law, Museums and the Return of Cultural Objects (Cambridge: Cambridge University Press, 2006).

17 Liszt, Völkerrecht 1898 (n. 11), 2-3.

18 García-Salmones Rovira, Mónica. 'The Politics of Interest in International Law'. European Journal of International Law 25(3) (2014), 765-793. 
One of them was authored by the Munich-based law professor Emanuel Ullmann. In his monograph, Ullmann acknowledged the collaboration in 'intellectual' issues to be an important area of the common activities of civilised states. Under this title, he discussed the international co-operation in the administration of cultural objects. Ullmann's (and also Liszt's) ${ }^{19}$ main example for cultural co-operation was the so-called Olympia treaty between Germany and Greece. ${ }^{20}$ Since 1874, this treaty has permitted Germany to conduct archaeological excavations and research on the ancient grounds of Olympia. ${ }^{21}$ The balanced treaty provisions demonstrate the co-operation between the two civilised states on an equal basis. For example, each state appointed a commissioner to supervise the compliance of the treaty (article 2) and most importantly, the export of the proceeds of the excavations to Germany was prohibited (article 6).

The comparison of the Olympia case with the cultural co-operation between France and Persia shows how the standard of civilisation mattered in these interactions among states. Unlike Greece, Persia was considered semicivilized under international law. ${ }^{22}$ Persia granted France a license to carry out archaeological research and excavations for the payment of 50,000 gold francs in $1895 .{ }^{23}$ This licence was valid for the whole country and deferred to France the right to decide where to excavate. ${ }^{24}$ In addition, France could also appropriate half of the excavation's proceeds and was allowed to export them. These exclusive rights were affirmed in a bilateral contract between France and Persia five years later on a visit of the Shah in Paris. ${ }^{25}$

Both legal documents that directed the conduct between France and Persia stood in sharp contrast to the Olympia treaty. To begin with, the permission to excavate in every region of the country and the license to appropriate and export half of the proceeds were regulated very differently in the Olympia treaty.

19 Liszt, Völkerrecht 1898 (n. 11), 189 et seq.

$20 \quad$ Ullmann, Emanuel. Völkerrecht (Tübingen: J. C. B. Mohr, 19o8), 412.

21 Vertrag zwischen Deutschland und Griechenland wegen Ausführung von archäologischen Ausgrabungen auf dem Boden des alten Olympia, 1.6.1875, Reichsgesetzblatt No. 19, 241-245.

22 Liszt, Völkerrecht 1898 (n. 11), 3; Oppenheim, International Law 1905 (n. 13), 33.

23 Convention relative au privilège des fouilles à exécuter en Perse, 12 May 1985, France Archives, Ministère de l'Europe et des Affaires étrangères, Traités et accords de la France TRA18950049.

24 Chevalier, Nicole. 'France and Elam', in The Elamite World, ed. Javier Álvarez-Mon, Gian Pietro Basello and Yasmina Wicks (Abingdon: Routledge, 2018), 41-62.

25 Convention relative à la concession des antiquités de la Perse, 30 October 19oo, France Archives, Ministère de l'Europe et des Affaires étrangères, Traités et accords de la France TRA19000021. 
Germany was prohibited from acquiring any antiquities and the excavations were carried out in close collaboration with Greek authorities. In contrast, France brought the Persian government to grant an unlimited extension of this exclusive right in a contract, in exchange France acknowledged Persia's international standing at the world exposition in Paris. The example shows that the status of civilisation, although not the only difference in these two cases, was an important factor with material consequences in the conception of cultural co-operations.

\subsection{Politics of Historiography: Challenging the Narrative of 'Civilising' the Laws of War}

It is a common narrative in the history of international law that the conduct of war and with it the laws of war became more civilised over the 19th and early 2oth century. ${ }^{26} \mathrm{~A}$ close study of the international legal doctrine gives evidence of a more diverse picture and the narrative of the ever more civilising laws of war appears to become a mere rhetorical metaphor of the long 19 th century. ${ }^{27}$ These norms only applied among civilised states and not to their relations with colonies. ${ }^{28}$ For the purpose of this study, the prohibition to destroy cultural objects and the regulations on war booty are of interest. ${ }^{29}$

Most current historiographies on the development of international cultural heritage law tell a narrative by reproducing authors, such as Johann Caspar Bluntschli. The Heidelberg-based law professor was one of the leading international lawyers of his time. ${ }^{30}$ In Bluntschli's public international law treatise,

26 See, e.g., Greenwood, Christopher. 'Historical Development and Legal Basis', in Oxford Handbook of International Humanitarian Law, ed. Dieter Fleck (Oxford: Oxford University Press, 2013), 1-44.

27 Jochnick, Chris and Roger Normand. 'The Legitimation of Violence: A Critical History of the Laws of War'. Harvard International Law Journal 35(1) (1994), 49-95; Vec, Miloš. 'All's Fair in Love and War or the Limits of the Limitations. Juridification of Warfare and its Revocation by Military Necessity', in Civility, Barbarism and the Evolution of International Humanitarian Law: Who Do the Laws of War Protect?, ed. Matt Killingsworth (Cambridge: Cambridge University Press, forthcoming).

28 See, e.g., Hull, Isabel V. Absolute Destruction: Military Culture and the Practices of War in Imperial Germany (Ithaca: Cornell University Press, 2005); Mégret, Frederic. 'From Savages to Unlawful Combatants: A Postcolonial Look at International Law's "Other"', in International Law and its Others, ed. Anne Orford (Cambridge: Cambridge University Press, 2006), 265-317.

29 Sandholtz, Wayne. Prohibiting Plunder: How Norms Change (Oxford: Oxford University Press, 2007); O'Keefe, Roger. The Protection of Cultural Property in Armed Conflict (Cambridge: Cambridge University Press, 2006), 18-22.

30 See, e.g., Röben, Betsy. Johann Caspar Bluntschli, Francis Lieber und das moderne Völkerrecht 1861-1881 (Baden-Baden: Nomos, 2003). 
he emphasised the progress that international law made concerning the legal status of monuments and artworks in wartime in the 1870 os. $^{31}$ Similarly, Richard Dana Jr., who edited the standard textbook of Henry Wheaton in its eighth edition some years earlier, stated that not only the destruction but also the seizure of such works would contradict liberal and civilised principles of warfare. ${ }^{32}$ Antoine Pillet, one editor of the Revue génèrale de droit international public, underlined the progress of international law regarding monuments and artworks in war since the art spoliations of Napoleon that filled the Louvre. ${ }^{33}$

The laws of war in the 19th and early 2oth century did not necessarily reflect the 'enthusiasm' 34 of these international lawyers. The different codification drafts, such as the Brussels Declaration $1874,{ }^{35}$ the Oxford Manual $1880^{36}$ and eventually the Hague Conventions of 1899 and 1907, ${ }^{37}$ at least foresaw an exception for 'military necessity' that allowed the destruction of monuments and artworks in certain circumstances. The seizure of cultural objects was even allowed under article 36 of the so-called U.S. Lieber Code $1863 \cdot{ }^{38}$

While standard narratives stress the positive impact of the civilisation discourse on the laws of war, there actually existed a pluralism of geographically different opinions in international legal doctrine on this topic until the end of the 19th century. ${ }^{39}$ The debates about the seizure of monuments and artworks in war times very instructively illustrate the ambivalent understanding of civilisation. Around the mid-19th century, two of the prominent proponents for the seizure of artworks were the German-U.S. jurist Francis Lieber and the U.S.-General and international lawyer Henry W. Halleck. In their view, the

31 Bluntschli, Johann Caspar. Das moderne Völkerrecht der civilisirten Staten als Rechtsbuch dargestellt (Nördlingen: C. H. Beck, 1878), 364.

32 Wheaton, Henry. Elements of International Law (London: Sampson Low, Son and Comp., 8th ed. 1866), 449-45o.

33 Pillet, Antoine. Le Droit de la Guerre (Paris: Arthur Rousseau, 1893), 339.

34 Koskenniemi, Martti. The Gentle Civilizer of Nations: The Rise and Fall of International Law 1870-1960 (Cambridge: Cambridge University Press, 2001), 4.

35 'Project of an International Declaration Concerning the Laws and Customs of War, 27 August 1874', in The Laws of Armed Conflicts. A Collection of Conventions, Resolutions and other Documents, eds. Dietrich Schindler and Jiří Toman (Leiden: Martinus Nijhoff, 3rd ed. 2004), 21-28.

36 'The Laws of War on Land. Manual Published by the Institute of International Law, 9 September 1880', in Schindler/Toman, Armed Conflicts 2004 (n. 35), 29-40.

37 Convention concerning the Laws and Customs of War on Land and its Annex: Regulations Respecting the Laws and Customs of War on Land, 18 October 1907, 205 CTS 277.

38 'Instructions for the Government of Armies of the United States in the Field. Promulgated as General Orders No. 100 by President Lincoln, 24 April 1863', in Schindler/Toman, Laws of Armed Conflicts 2004 (n. 35), 3-20.

39 See also Vrdoljak, International Law 2006 (n. 16), 28. 
entire enemy's property could be appropriated because international law still did not include an obligation to spare cultural goods at the time. ${ }^{40}$

In the last quarter of the 19th century, interesting oppositions to the traditional civilising narrative developed. The two British scholars James Lorimer ${ }^{41}$ and Henry S. Maine ${ }^{42}$ developed a remarkable approach using the concept of civilisation in relation with the laws of war to argue for the seizure of artworks in war times. James Lorimer stated that civilisation could benefit from the transfer of artworks to another country, because those cultural objects might become accessible for 'the public' for the first time. ${ }^{43}$ This was his main argument why art plunders, such as the Napoleonic ones at around 180o, were principally justifiable under international law. ${ }^{44}$ Such an argument undoubtedly corrupted the common narrative of civilisation as traditionally understood in relation to the laws of war.

In his writing about the seizure of artworks under international law, Henry S. Maine deliberated whether the accumulation of many masterpieces of art might actually promote civilisation. Maine concluded with reference to the art restitutions from Paris after Napoleon's defeat that the technological progress and the increased personal mobility since those times have made the cultural monuments of Europe just as accessible as if they were concentrated in one capital. ${ }^{45}$ Maine is perhaps the only legal author considering technological innovations when evaluating the advantages of such art seizures.

The confrontation with the historical counter discourse of civilisation contests the traditional historiography of international cultural heritage law for the 19th and early 2oth century. Despite the consensus that civilisation mattered as a concept for international law, ${ }^{46}$ it becomes clear from these examples that

40 Halleck, Henry W. International Law; Or, Rules Regulating the Intercourse of States in Peace and War (New York: D. Van Nostrand, 1861), 451; Lieber, Francis. Manual of Political Ethics, Vol. 2 (Boston: Charles C. Little and James Brown, 1839), 663 et seq.

41 Koskenniemi, Martti. 'Race, Hierarchy and International Law: Lorimer's Legal Science'. European Journal of International Law 27(2) (2016), 415-29.

42 Mantena, Karuna. Alibis of Empire: Henry Maine and the Ends of Liberal Imperialism (Princeton: Princeton University Press, 2010).

43 Lorimer, James. The Institutes of the Law of Nations. A Treatise of the Jural Relations of Separate Political Communities, Vol. 2 (Edinburgh/London: William Blackwood \& Sons, 1884), 79 .

44 Savoy, Bénédicte. Kunstraub, Napoleons Konfiszierungen in Deutschland und die europäischen Folgen (Vienna: Böhlau Verlag, 2011).

45 Maine, Henry S. International Law (London: John Murray, 189o), 195-197.

46 For a good elaboration of the historical argument, see, e.g., Pitts, Jennifer. Boundaries of the International. Law and Empire (Cambridge: Harvard University Press, 2018), 7. 
the concrete understanding of civilisation varied among scholars and manifested itself differently in different places at different times.

\subsection{Codifying Inequalities: The Colonial Bias of IMO-Drafts in the League of Nations Era}

The world of cultural co-operation was newly organized after World War I. The League of Nations was founded and various institutions, such as the International Commissions for Intellectual Co-operation, the International Institute of Intellectual Co-operation and the International Museums Office (IMO), were established to address questions of cultural matters in a broad sense. ${ }^{47}$ Despite the internationalisation, the concept of civilisation remained vital for this field. The General Assembly of the League of Nations made this explicit in its recommendation from 10 October 1932, which stated that the preservation of artistic and archaeological patrimony lies in the interest of the civilised states. ${ }^{48}$

This marked an important turn towards new international governance mechanisms for cultural objects. ${ }^{49}$ Many states and individuals from different nations were involved in those efforts and particularly representatives of the peripheries actively shaped the discussions. However, when it came to the formulation of international legal instruments, the colonial bias of the civilisation discourse was still present.

The codification efforts of the International Museums Office to prepare multilateral instruments to protect cultural heritage in the 1930s give an instructive example of the lasting effect of the civilisation concept in international law. The IMO set up a drafting committee for this task headed by the Belgian international lawyer Charles de Visscher. ${ }^{50}$ The aim was to compile two conventions on cultural objects, one for the conduct in times of peace and one for the times of war, but also to find a narrative to legitimise these proposals.

47 For an overview of the intellectual co-operation, see e.g. Laqua, Daniel. 'Transnational Intellectual Cooperation, the League of Nations, and the Problem of Order'. Journal of Global History 6(2) (2011), 223-247; Brzeziński, Andrzej M. 'The Organization and Forms of International Intellectual Cooperation within the League of Nations (1922-1939)'. Przegląd Zachodni 1 (2017), 53-70.

48 'Recommandations de l'Assemblée de la Société des Nations du 1o Octobre 1932'. Art et Archéologie. Recueil de Législation Comparée et de Droit International 1 (1939), 114 et seq.

49 See also Vrdoljak, International Law 2006 (n. 16), 103-117.

50 Verhoeve, Joe. 'Charles de Visscher: Living and Thinking International Law'. European Journal of International Law 11(4) (2000), 887-904. 
Visscher wrote a seminal article for the Revue de Droit international, which set the frame for these new regulatory fields in $1935 .{ }^{51}$ To justify the convention on the ius in bello, he relied on a vast material of legal debates and codifications since the 19th century, but he also criticised other legal efforts to protect monuments in the course of war. ${ }^{52}$ In a preliminary report to the IMO, Visscher particularly dismissed the so-called 'Roerich Pact', a treaty created on initiative of the Russian artist Nicolas Roerich for protecting monuments and signed by many American states in $1935 .{ }^{53}$ Instead of giving credits to the initiative, Visscher polemicized against the Roerich Pact for not including a 'military necessity' exception to justify damages on monuments in war times. ${ }^{54}$ This would make the treaty impractical for Europe. Its plurality of cultural treasures and historic cities would make, in contrast to the in this sense culturally short fallen American states, the conduct of war without a military exception clause impossible. Consequently, such a treaty might be sustainable there, but it would not be viable in Europe. With this argumentation, Visscher gave evidence of his and international law's Eurocentrism in the drafting of laws and how civilisation was used to argue for and against certain norms at the time.

Even more interesting than Visscher's remark about the convention on the laws of war was his narrative for the juridification of the norms in peace times. At this point, Visscher applied a comparative and historical point of view to legitimise the new legal regime of private international law. ${ }^{55} \mathrm{He}$ established that the opinion among the major civilised states in Europe was consistent in respect of the status of artworks in private international law by discussing domestic legal rules of European civilised states, such as France, Italy, Austria, Germany, and Spain. ${ }^{56}$ In consequence, the understanding of European nation states was authoritative for international normative regimes. The final Draft international convention for the protection of national collections

51 De Visscher, Charles. 'La Protection Internationale des Objets d'Art et des Monuments Historique'. Revue de droit international et de législation comparée 16 (1935), 32-74, 246-288.

52 De Visscher, Charles. 'Rapport Préliminaire Présenté au Comité de Direction de l'Office International des Musées, le 12 Octobre 1936'. Art et Archéologie. Recueil de Législation Comparée et de Droit International 2 (1940), 47-55.

53 Treaty on the Protection of Artistic and Scientific Institutions and Historic Monuments (Roerich Pact), 15 April 1935, CLXVII LnTS 289; see also Roerich, Nicholas. Roerich Banner of Peace (New York: Roerich Museum Press, 1931).

54 De Visscher, 'Rapport Préliminaire' 1940 (n. 52), 5 o.

55 For the entanglement between comparative law and private international law, see Reimann, Mathias. 'Comparative Law and Private International Law', in The Oxford Handbook of Comparative Law, eds. Mathias Reimann and Reinhard Zimmermann (Oxford: Oxford University Press, 20o6), 1363-1396.

56 De Visscher, 'La Protection Internationale' 1935 (n. 51), 34-46. 
of art and history of 1939 also included openly discriminatory regulations for the colonies:

Article 12. Any High Contracting Party may, at the time of its signature, ratification or accession, declare that in accepting the present Convention it assumes no obligation whatsoever in respect of the whole or part of its colonies, protectorates, overseas territories, territories placed under its sovereignty or territories for which a mandate has been entrusted to it. ${ }^{57}$

According to this draft article, it would have been upon the empires to decide about the application of these normative regimes on their peripheries. This would have not only bypassed the question of restitution of colonial treasures and cultural objects back then, but, because of the intertemporal character of international law, might actually have this effect until today. ${ }^{58}$ Although these drafts were never ratified, they indicate the continuing importance of the civilisation discourse for international cultural heritage law in the 2oth century.

\section{The Different Roles of the Law in the 'Civilisation' Discourse}

The case studies of this section analyse various roles that cultural heritage laws played for different actors in diverse international settings. The standard of civilisation highly shaped these contexts; however, this does not mean that there was no agency on the part of the colonised. This section attempts to provide a more nuanced historic understanding by questioning the solely protective purposes of cultural heritage laws, but also to emphasise the different contexts in which such norms developed.

The focus of this section will be on interactions outside from armed conflicts and on cases that involve more controversial factual constellations regarding current questions of restitution. The fact patterns developed in this section are also intended to help evaluating restitution claims today. While the second section illustrated how the standard of civilisation was crucial for the evolution of the international legal discourse on cultural heritage, this section

57 Office International des Musées, 'Le Projet Définitif Établi en 1939 en Vue de la Conférence Diplomatique'. Art et Archéologie. Recueil de Législation Comparée et de Droit International 1 (1939), 78-87, Art. 12.

$5^{8}$ Shaw, Malcolm N. International Law (Cambridge: Cambridge University Press, 8th ed. 2017), 702 . 
shall document how the discourse of civilisation impacted the development of regional and local cultural heritage laws in the 19th and 2oth century.

Three different configurations shaped the development of these laws on a regional and national level: First, (semi-)peripheral states used cultural heritage laws with an emancipatory purpose. Second, empires used colonial laws to govern, appropriate and legitimise with reference to their civilising duty such interventions into the cultural heritage of other peoples. Third, laws also aimed to assure one's own national identity and political independence, particularly by excluding foreign nationals after a phase of colonization or foreign domination.

\subsection{Using Culture as a Means of Emancipation in the International Community}

Some state actors intended to influence their standing in the international community by using domestic regulations on cultural objects and antiquities. These legislations were oriented towards western legal standards or were even drafted by European authors. ${ }^{59}$ One aim of these norms was to participate in the discourse of civilisation by protecting what was regarded valuable among civilised states. A country with a contested position on the international level that used domestic cultural heritage laws in this sense was the Ottoman Empire. ${ }^{60}$

The German archaeologist Philipp Anton Déthier drafted the first 'antiquities law' in 1874 to meet the expectations of European excavators and favour their needs. ${ }^{61}$ As a consequence of this regulation, Europeans could rather easily acquire cultural heritage on the territory of the Ottoman Empire. However, it was not before 1907 that Islamic artworks were considered worthy to protect under these laws. ${ }^{62}$ This late consideration of Islamic artworks and the relaxed norms to obtain antiquities indicate that the laws were directed to enable

59 See also the newly launched project Decolonial Comparative Law by Ralf Michaels and Lena Salaymeh, available at: https://www.mpipriv.de/en/pub/research/decolonial _comparative_law.cfm (last accessed on 14 September 2020).

6o Öszu, Umut. 'Ottoman Empire', in The Oxford Handbook of the History of International Law, eds. Bardo Fassbender and Anne Peters (Oxford: Oxford University Press, 2012), 429-448.

61 Khater, Antoine. Le Régime Juridique des Fouilles et des Antiquités en Égypte (Kairo: Imprimerie de l'Institut Français d'Archéologie Orientale, 1960), 275 et seq.

62 Hitzel, Frédéric. 'Osman Hamdi Bey et les Débuts de l'Archéologie Ottomane', in Turcica 42 (2010), 167-19o. 
international cultural co-operations and to gain recognition on the international plane. ${ }^{63}$

The Ottoman Empire also saw in the adoption of European institutions a way to demonstrate its international status as civilised empire. A telling example for this is the archaeological museum in Istanbul. ${ }^{64}$ The Ottoman education minister and reformer of the Tanzimat period, Münif Pasha, held an instructive speech at the opening of the museum on 17 August 188o. Münif Pasha alluded to the acknowledgement that he expected for the new museum from European states. Consequently, the interest to protect these objects was not only a cultural, but also an emancipatory one:

The opening of a museum in Istanbul similar to those in other civilised countries was the hope of our progressing nation. [...] There is no need to go on at length about the benefits of such museums. They show the level of civilisation of past peoples and their step-by-step progress. [...] Everybody knows the great effects of archeology on European Civilisation. [...] Until now, Europeans have used various means to take the antiquities of our country away, and they did this because they did not see an inclination toward this in us. ${ }^{65}$

Other national legislation, institutions and cultural co-operations, such as in Latin American states, followed similar patterns. El Salvador established a national library to promote the education of its people with reference to institutions in other civilised states. ${ }^{66}$ Honduras signed an excavation treaty with the Peabody Museum of Harvard University to ensure the appreciation of its historical remains by western archaeologists. ${ }^{67}$

The importance of domestic cultural heritage legislation for the international standard of civilisation is remarkably displayed by a repertory of the

63 Marchand, Suzanne. 'Orientalism as Kulturpolitik. German Archeology and Cultural Imperialism in Asia Minor', in Volksgeist as Method and Ethic. Essays on Boasian Ethnography and the German Anthropological Tradition, ed. George W. Stocking (Madison: University of Wisconsin Press, 1996), 298-336.

64 For the role of museums, see, e.g., Meyer, Andrea and Bénédicte Savoy, eds. The Museum is Open. Towards a Transnational History of Museums 1750-1940 (Berlin: De Gruyter, 2014).

65 Shaw, Wendy. Possessors and Possessed. Museum, Archaeology, and the Visualization of History in the Late Ottoman Empire (Berkeley: University of California Press, 2003), 93 et seq.

66 El Salvador, Decreto de Fundacion de la Biblioteca Nacional, 1 July 1870, El Constitucional 1870, vol. 4, no. 40 .

67 Honduras, Acuerdo por el traspaso de una concesion al Peabody Museum, 20 July 1891, UNEsco Database of National Cultural Heritage Laws, available at: https://en.unesco.org/ cultnatlaws/list (last accessed on 14 September 2020). 
Prussian lawyer Alexander von Wussow. He collected the national cultural heritage legislation of the civilised states around the world and published them in $1885 .{ }^{68}$ This collection included not only the heritage laws of European states, but also those of China, Japan, Brazil, Mexico and the Ottoman Empire. Being civilised meant for him having an historical conscience about the past and to protect its remains. As a result, passing legislation that protected monuments was an important element in the discourse of civilisation in international law at that time.

\section{2 \\ 'Colonial Protection': Justifying Interventions into Foreign Cultural Heritage}

Cultural heritage laws were used to appropriate and govern foreign cultural heritage under certain colonial contexts in the 19th and 2oth century. Although the standard of civilisation contributed in various ways to a narrative of protection for these laws, it also legitimised the legal interventions in foreign cultural heritage. Some encounters in Asian countries provide insights into these practices and the construction of specific legislative aims.

The French École Française d'Extrême-Orient was one of the important European institutions in Asia that dealt with cultural heritage. In the French colony of Indochina, the colonial government imposed laws to regulate the administration of the 'cultural treasures' of the colony. ${ }^{69}$ One site that received specific attention was Ângkôr, which was legally transformed into an archaeological park in 1925 to meet the interests of European tourists. ${ }^{70}$ In a report to the French president, Édouard Daladier, the colonial minister of France, wrote about Indochina in the same year:

Under reservation of the sovereign rights of the protected in French Indochina, the properties, which presents from an artistic and historic point of view a public interest for conservation, are classified as historic monuments by the governor general on proposition of the director of the École Française d'Extrême-Orient. The protection of these treasures is a task that imposes itself imperially on the French authority $[\ldots ..] .^{71}$

68 Wussow, Alexander von. Die Erhaltung der Denkmäler in den Kulturstaaten der Gegenwart (Berlin: Carl Heymanns Verlag, 1885).

69 Le Governeur général de l'Indochine, Arrête sur la conservation des monuments et objets ayant un intérêt historique ou artistique, 9 March 190o, unesco Database (n. 67).

70 Le Gouverneur général de l'Indochine, Arrêté créant le parc archéologique d'Angkor, 30 October 1925, Bulletin de l'Ecole française d'Extrême-Orient, vol. 26, 677 .

71 Le Ministre des Colonies. 'Rapport au Président de la République Française, December 23, 1924'. Bulletin de l'Ecole francaise d'Extrême-Orient 26 (1926), 526-527 (author's translation). 
This report indicates that the protection of cultural monuments was considered a civilising responsibility. At the same time, it formed a justification narrative to enable legislation and a lawful acquisition of cultural artefacts.

The mandate system of the League of Nations legally and institutionally envisaged another more complex organization for the administration of cultural heritage. The league's covenant foresaw a distinction between the mandates according to their perceived 'civilisation stage'. Article 22 of the Covenant differed between communities formerly belonging to the 'Turkish Empire' (A), 'Central Africa' (B) and 'South-West Africa and certain of the South Pacific Islands' (C). ${ }^{72}$ Cultural heritages laws were put into place in the A-mandates Palestine, Syria-Lebanon, and Iraq by the mandate powers France and Great Britain. ${ }^{73}$ These laws regulated the appropriation, the export, and the excavation of antiquities located in each one of these mandate territories. The Permanent Mandate Commission of the League of Nations acted as a type of supervisor in this system of foreign administration. ${ }^{74}$

Despite this supervisory function of the league, the different laws benefited the western archaeologists and the mandate powers with generous provisions for acquiring and exporting antiquities. ${ }^{75}$ The exploitations went so far that the Syro-Palestinian Congress addressed in 1925 a petition to the Permanent Mandate Commission to complain inter alia about the careless treatment and appropriations of their cultural patrimony. ${ }^{76}$ Despite the trusteeship relation of the mandate powers with their protégés and the international tutelages, the administration followed a pattern of domination and the laws just covered these hegemonic structures under the rhetoric of 'protection'.

72 For the mandate system in general, see Pedersen, Susan. The Guardians. The League of Nations and the Crisis of Empire (Oxford: Oxford University Press, 2015) and for the A-Mandates Schayegh, Cyrus and Andrew Arsan, eds. The Routledge Handbook of the History of the Middle East Mandates (Abingdon: Routledge, 2015).

73 For an overview, see Goode, James F. Negotiating for the Past. Archaeology, Nationalism, and Diplomacy in the Middle East, 1919-1941 (Austin: University of Texas Press, 2007).

74 Magee, Peter. 'The Foundations of Antiquities Departments', in A Companion to the Archeology of the Ancient Near East, ed. Daniel T. Potts (Malden: Blackwell Publishing, 2012), 70-86.

75 See, e.g., Israel/Palestine, Antiquities Ordinance 1920, 15 October 1920, Official Gazette of the Government of Palestine, Nr. 29/9, 4-16; Syria/Libanon, Arrête No. 207 Portant règlement sur les antiquités en Syrie et au Liban, 26 March 1926, Bulletin officiel des actes administratifs du Haut Commissariat 5, no. 8, 136-139.

76 League of Nations, Permanent Mandates Commission, Minutes of the 8th Session (Extraordinary) including the Report of the Commission to the Council, 8 March 1926, C.174.M.65.1926.VI., 174-186. 


\subsection{Reclaiming Cultural Heritage in the Struggles for National Independence}

The dominant discourse of civilisation also received backlash from former colonies or imperially dominated countries. ${ }^{77}$ The resistance materialised also in cultural heritage norms, which had the purpose to reassure one's own independence and national identity. ${ }^{78}$ Such constellations arose in Iraq, China and Persia around the 1930s. International cultural co-operations with western powers became for these states a venue of opposition against perceived colonial and imperial policies.

Iraq gained independence from Great Britain's mandate rule and became a new member to the League of Nations in 1932. During this process, the Permanent Mandate Commission debated whether the Arabic state should be legally obliged to continue providing international access to its cultural treasures. ${ }^{79}$ The proposal was finally refused with the argument that such a provision would prevent Iraq from showing a sign of generosity to its new co-members within the League of Nations by continuing the cultural cooperations. The members of the Permanent Mandate Commission were convinced that Iraq would seize this opportunity to obtain the respect of the civilised community for such a friendly act. ${ }^{80}$ However, in contrast to their assumption, Iraq soon passed a new 'antiquity law' 81 that strictly regulated excavations and prohibited the acquisition of antiquities by foreign archaeological explorations. ${ }^{82}$ The interests of the civilised world in continuing archaeological excavations in the country were neglected.

In a comparable way, China issued a new law to limit the entry of foreign archaeologists in its territory. ${ }^{83}$ The French hegemony over the archaeological

77 For the early 2oth century, see also Vrdoljak, International Law 2006 (n. 16), 73-87.

${ }_{78}$ A similar dynamic existed in Germany after World War I, see Obenaus, Maria. Für die Nation gesichert? Das „Verzeichnis der national wertvollen Kunstwerke“: Entstehung, Etablierung und Instrumentalisierung 1919-1945 (Berlin: De Gruyter, 2016), 22-44.

79 League of Nations, Permanent Mandates Commission, Minutes of the 21st Session, 29 December 1931, C.83o.M.411.1931.VI., 118 et seq.

$80 \quad$ Ibid., 119 .

81 For an overview, see Bernhardsson, Magnus T. Reclaiming a Plundered Past: Archaeology and Nation Building in Modern Iraq (Austin: Texas University Press, 2005).

82 Magee, 'The Foundations of Antiquities Departments' 2012 (n. 74), 70-86; for a biography of the director of the antiquities department at that time, see Cleveland, William L. The Making of an Arab Nationalist. Ottomanism and Arabism in the Life and Thought of Sati' Al-Husri (Princeton: Princeton University Press, 1971).

83 China, Executive Yuan, Rules Relating to the Participation of Foreign Academic Organization or Private Individuals in the Excavation of Relics, 16 March 1935, UNEsCo Database (n. 67). 
heritage of Persia came to an end in $1927 .{ }^{84}$ Some years later, the administration of the country's cultural heritage was newly regulated in a revised law that was characterised by a more restrictive approach to the issue. ${ }^{85}$ These cases show that political independence materialised also in a re-appropriation of the own cultural heritage and the rejection of the dominant discourse of civilisation that demanded international cultural co-operation.

Conclusion: Resistance and the Continuities of a Problematic Structure

The momentum of decolonization and the new international venues established after World War II promised a change in international cultural heritage law towards the restitution of cultural heritage from colonial contexts of acquisition. ${ }^{86}$ This section draws on the UN General Assembly resolutions as an example for the lasting effects of the civilisation discourse and the resistance against it by using international legal mechanisms.

The ambivalent history of cultural heritage in international law did not end with decolonization. The restitution of colonial plundered art nowadays is one of the most discussed aspects of international cultural law. ${ }^{87}$ Restitution claims of African and Asian states have lately filled the headlines of several news media and are globally discussed among scholars. ${ }^{88}$ An important cornerstone in the recent development is the report of Felwine Sarr and Bénédicte Savoy for the French government that argues for a return of more than

84 Accord de principe conclu entre le gouvernement de Sa Majesté Impériale le schah de Perse et le gouvernement de la République française au sujet de l'abolition de la convention franco-persane de 1900 relative au monopole des fouilles archéologiques, 18 October 1927, France Archives, Ministère de l'Europe et des Affaires étrangères, Traités et accords de la France, TRA1927005o.

85 Iran, Règlement d'application de la Loi du 12 Aban - Mah 1309 relative à la conservation des antiquités de l'Iran, 3 November 1930, unesco Database (n. 67), Art. 38 and 47.

86 Vrdoljak, International Law 2006 (n. 16), 197-227.

87 Hauser-Schäublin, Brigitta and Lyndel V. Prott. 'Introduction: Changing Concepts of Ownership, Culture and Property', in Cultural Property and Contested Ownership. The Trafficking of Artefacts and the Quest for Restitution, ed. Brigitta Hauser-Schäublin and Lyndel V. Prott (Abingdon: Routledge, 2016), 1-20.

88 One of the latest successful restitution claims was brought by the Philippines against the U.S. concerning the Balangiga bells. See Gutierrez, Jason. 'U.S. Returns Bells Taken as War Booty From Philippines in 1901'. The New York Times (11 December 2018), available at: https://www.nytimes.com/2018/12/11/world/asia/balangiga-bells-united-states -philippines.html (last accessed on 14 September 2020). 
100 ooo objects looted in Africa. ${ }^{89}$ Today's debates thus are not new but rather continuing the discussion since decolonization in the 1970s. ${ }^{90}$ The claims for repatriation come together with the demand to acknowledge the colonial wrongs and sufferings of colonised peoples. ${ }^{91}$

The engagement of the UN General Assembly with the restitution of colonial plundered art already started soon after the adoption of the UNESCO Convention 1970 and the World Heritage Convention in $1972 .{ }^{92}$ The government of Zaire, today's Democratic Republic of Congo, first proposed to the General Assembly a resolution that openly addressed the issue in $1973 \cdot{ }^{93}$ The condemning language of the draft resolution eventually entered the UN resolution: 'Deploring the wholesale removal, virtually without payment, of objets d'art from one country to another, frequently as a result of colonial and foreign occupation. ${ }^{94}$ The resolution suggested restitution as a means to rectify the wrongs of the past.

As a consequence of this direct language, many states with a colonial or imperial past abstained from voting on the resolution, but still a majority of 113 of the then $135 \mathrm{UN}$ member states voted in its favour. In the following years, the General Assembly regularly instructed the UN Secretary General to report on restitutions of cultural objects. ${ }^{95}$ These reports indicate that the abstaining countries preferred bilateral negotiations and the forum of UNESCO to

89 Sarr, Felwine and Bénédicte Savoy. The Restitution of African Cultural Heritage. Toward a New Relational Ethics (2018), available at: http://restitutionreport2018.com/sarr_savoy_ en.pdf (last accessed on 14 September 2020).

90 See also Fitschen, Thomas. '30 Jahre „Rückführung von Kulturgut"'. Vereinte Nationen $52(2)(2004), 46-51$.

91 Krueger, Anna. Die Bindung der Dritten Welt an das postkoloniale Völkerrecht. Die Völkerrechtskommission, das Recht der Verträge und das Recht der Staatennachfolge in der Dekolonialisierung (Berlin: Springer, 2018); Craven, Matthew. The Decolonization of International Law. State Succession and the Law of Treaties (Oxford: Oxford University Press, 2007).

92 Convention on the means of prohibiting and preventing the illicit import, export and transfer of ownership of cultural property, 14 November 1970, 823 UNTS 231; Convention concerning the Protection of the World Cultural and Natural Heritage, 16 November 1972, 1037 UNTS 151.

93 United Nations, Letter from the Permanent Representative of the government of Zaire to the United Nations addressed to the President of the General Assembly, A/9199, 6 November 1973 .

94 United Nations, General Assembly, Restitution of works of arts to countries victims of expropriation, A/RES/3187(XXVIII), 18 December 1973 (italics in original).

95 See, e.g., United Nations, General Assembly, Restitution of works of arts to countries victims of expropriation, A/RES/3391 (XXX), 19 November 1975, para. 7. 
resolve the disputes instead of the UN General Assembly. ${ }^{96}$ Subsequently, an own 'Intergovernmental Committee for promoting the return of cultural property to its countries of origin or its restitution in case of illicit appropriation' was set up by UNESCO to mediate in cases of conflicts in $1978 .{ }^{97}$ Moreover, the second World Conference on Cultural Policies in 1982 formulated a set of recommendations for the return of cultural objects, ${ }^{98}$ but the universality of cultural heritage was invoked by some delegations to refuse restitution claims at the same time. ${ }^{99}$

Neither the recommendations nor the new institutions were very successful in reconciling conflicts. The support for the still biannually proposed UN General Assembly resolutions on restitution diminished over time. ${ }^{100}$ In 1997, the restitution resolution was only adopted by 87 votes ( 23 states abstaining, 75 states opposed), also because it contained a passage emphasising the positive value of restitutions for the relations between developed and developing countries. ${ }^{101}$

Further international initiatives, such as the UNIDROIT Convention, ${ }^{102}$ refrained from addressing the questions of colonial plundered cultural heritage. ${ }^{103}$ The intertemporal character of international law was often referred to for arguing against the formulation of legal claims to compensate or repatriate cultural property. ${ }^{104}$ The existence of the UN General Assembly resolutions

96 See, e.g., United Nations, Secretary General, Report on the Restitution of works of art to countries victims of expropriations, A/32/203, 27 September 1977; or United Nations, General Assembly, 3oth Session, 2410th Plenary Meeting, 30A/PV.2410, 19 November 1975, 928 et seq.

97 Unesco, General Conference, Statutes of the Intergovernmental Committee for Promoting the Return of Cultural Property to its Countries of Origin or its Restitution in Case of Illicit Appropriation, 2oC/Res. 4/7.6/5, 28 November 1978.

98 UnEsCo, World Conference on Cultural Policies, Final Report, CLT/MD/1, November 1982, 94-97.

99 Ibid., 31.

100 See, e.g., United Nations, General Assembly, Return or restitution of cultural property to the countries of origin, A/RES/40/19, 21 November 1985.

101 United Nations, General Assembly, Return or restitution of cultural property to the countries of origin, A/REs/52/24, 18 December 1997, para. 2.

102 UNIDROIT Convention on Stolen or Illegally Exported Cultural Objects, 24 June 1995, 2421 UNTS 457 .

103 See Unidroit Secretariat. 'Unidroit Convention on Stolen or Illegally Exported Cultural Objects: Explanatory Report', in Uniform Law Review 3 (2001), 476-564.

104 Taşdelen, Alper. The Return of Cultural Artefacts. Hard and Soft Law Approaches (Berlin: Springer, 2016), 91-93. 
as 'narrative norms' about the colonial past of cultural heritage underline the urgency of the situation, but fail to provide legal rights as a remedy. ${ }^{105}$

The current constellation of most domestic and the international legal order are regularly perceived to obstruct restitution claims despite the long history of resistance. Such a history demonstrates not only the different ways in which the concept of civilisation in international law contributed to shape international cultural heritage law regimes, but also how different actors related to it. Embedding a critical narrative into the traditional historiography of international cultural heritage law emphasises the deficiencies of the contemporary legal order and might provide a perspective for future improvements.

\section{Bibliography}

Anghie, Antony. 'Finding the Peripheries: Sovereignty and Colonialism in Nineteenth-Century International Law'. Harvard International Law Journal 40(1) (1999), 1-8o.

Anghie, Antony. Imperialism, Sovereignty and the Making of International Law (Cambridge: Cambridge University Press, 2005).

Becker Lorca, Arnulf. Mestizo International Law. A Global Intellectual History 1842-1933 (Cambridge: Cambridge University Press, 2014).

Benton, Lauren and Lisa Ford. Rage for Order. The British Empire and the Origins of International Law, 1800-1850 (Cambridge: Harvard University Press, 2016).

Bernhardsson, Magnus T. Reclaiming a Plundered Past:Archaeology and Nation Building in Modern Iraq (Austin: Texas University Press, 2005).

Bluntschli, Johann Caspar. Dasmoderne Völkerrecht der civilisirten Staten als Rechtsbuch dargestellt (Nördlingen: C.H. Beck, 1878).

Brzeziński, Andrzej M. 'The Organization and Forms of International Intellectual Cooperation within the League of Nations (1922-1939)'. Przeglad Zachodni 1 (2017), 53-70.

Chevalier, Nicole. 'France and Elam', in The Elamite World, ed. Javier Álvarez-Mon, Gian Pietro Basello, Yasmina Wicks (Abingdon: Routledge, 2018), 41-62.

Cleveland, William L. The Making of an Arab Nationalist. Ottomanism and Arabism in the Life and Thought of Sati' Al-Husri (Princeton: Princeton University Press, 1971).

Craven, Matthew. The Decolonization of International Law. State Succession and the Law of Treaties (Oxford: Oxford University Press, 2007).

105 Jayme, Erik. 'Narrative Norms in Private International Law - The Example of Art Law'. Recueil des Cours de l'Académie de Droit International de La Haye 375 (2014) 19-5o. 
De Visscher, Charles. 'La Protection Internationale des Objets d'Art et des Monuments Historique', Revue de droit international et de legislation comparee 16 (1935), 32-74, 246-88.

De Visscher, Charles. 'Rapport Preliminaire presente au Comite de Direction de l'Office international des Musees, le 12 Octobre 1936'. Art et Archeologie. Recueil de Legislation Comparee et de Droit International 2 (1940), 47-55.

Fitschen, Thomas. '30 Jahre „Rückführung von Kulturgut'. Vereinte Nationen $5^{2(2)}$ (2004), 46-51.

García-Salmones Rovira, Mónica. 'The Politics of Interest in International Law'. European Journal of International Law 25(3) (2014), 765-793.

Gaudenzi, Bianca and Astrid Swenson. 'Looted Art and Restitution in the Twentieth Century - Towards a Global Perspective'. Journal of Contemporary History 52(3) (2017), 491-518.

Gong, Gerrit W. The Standard of 'Civilisation' in International Society (Oxford: Oxford University Press, 1984).

Goode, James F. Negotiating for the Past. Archaeology, Nationalism, and Diplomacy in the Middle East, 1919-1941 (Austin: University of Texas Press, 2007).

Greenfield, Jeanette. The Return of Cultural Treasures (Cambridge: Cambridge University Press, 2007).

Greenwood, Christopher. 'Historical Development and Legal Basis', in Oxford Handbook of International Humanitarian Law, ed. Dieter Fleck (Oxford: Oxford University Press, 2013), 1-44.

Guizot, François. Histoire Générale de la Civilisation en Europe (Paris: Pichon et Didier, 1828).

Gutierrez, Jason. 'U.S. Returns Bells Taken as War Booty From Philippines in 19o1'. The New York Times (11 December 2018), available at: https://www.nytimes.com/ 2018/12/11/world/asia/balangiga-bells-united-states-philippines.html (last accessed on 14 September 2020).

Halleck, Henry W. International Law; Or Rules Regulating the Intercourse of States in Peace and War (New York: D. Van Nostrand, 1861).

Hauser-Schäublin, Brigitta and Lyndel V. Prott. 'Introduction: Changing Concepts of Ownership, Culture and Property', in Cultural Property and Contested Ownership. The Trafficking of Artefacts and the Quest for Restitution, ed. Brigitta Hauser-Schäublin and Lyndel V. Prott (Abingdon: Routledge, 2016), 1-20.

Hermann, Florian. Das Standardwerk. Franz von Lisztund das Völkerrecht (Baden-Baden: Nomos, 2001).

Hitzel, Frédéric. 'Osman Hamdi Bey et les débuts de l'archéologie ottomane'. Turcica 42 (2010), 167-19o.

Hull, Isabel V. Absolute Destruction: Military Culture and the Practices of War in Imperial Germany (Ithaca: Cornell University Press, 2005). 
Jayme, Erik. 'Narrative Norms in Private International Law - The Example of Art Law'. Recueil des Cours de l'Académie de Droit International de La Haye 375 (2014) 19-5o.

Jochnick, Chris and Roger Normand. 'The Legitimation of Violence: A Critical History of the Laws of War'. Harvard International Law Journal 35(1) (1994), 49-95.

Khater, Antoine. Le Régime Juridique des Fouilles et des Antiquités en Égypte (Kairo: Imprimerie de l'Institut Français d'Archéologie Orientale, 1960).

Koskenniemi, Martti. 'Race, Hierarchy and International Law: Lorimer's Legal Science'. European Journal of International Law 27(2) (2016), 415-429.

Koskenniemi, Martti. The Gentle Civilizer of Nations: The Rise and Fall of International Law 1870-1960 (Cambridge: Cambridge University Press, 2001).

Krueger, Anna. Die Bindung der Dritten Welt an das postkoloniale Völkerrecht. Die Völkerrechtskommission, das Recht der Verträge und das Recht der Staatennachfolge in der Dekolonialisierung (Berlin: Springer, 2018).

Laqua, Daniel. 'Transnational Intellectual Cooperation, the League of Nations, and the Problem of Order'. Journal of Global History 6(2) (2011), 223-247.

League of Nations, Permanent Mandates Commission, Minutes of the 8th Session (Extraordinary) including the Report of the Commission to the Council, 8 March 1926, C.174.M.65.1926.vi.

League of Nations, Permanent Mandates Commission, Minutes of the 21st Session, 29 December 1931, C.83o.M.411.1931.VI.

Lieber, Francis. Manual of Political Ethics, Vol. 2 (Boston: Charles C. Little and James Brown, 1839).

Liszt, Franz von. Das Völkerrecht systematisch dargestellt (Berlin: Verlag von O. Haering, 1898).

Lorimer, James. The Institutes of the Law of Nations. A Treatise of the Jural Relations of Separate Political Communities, Vol. 2 (Edinburgh: William Blackwood \& Sons, 1884).

Magee, Peter. 'The Foundations of Antiquities Departments', in A Companion to the Archeology of the Ancient Near East, ed. Daniel T. Potts (Malden: Blackwell Publishing, 2012), 70-86.

Maine, Henry S. International Law (London: John Murray, 189o).

Mantena, Karuna. Alibis of Empire: Henry Maine and the Ends of Liberal Imperialism (Princeton: Princeton University Press, 2010).

Marchand, Suzanne. 'Orientalism as Kulturpolitik. German Archeology and Cultural Imperialism in Asia Minor', in Volksgeist as Method and Ethic. Essays on Boasian Ethnography and the German Anthropological Tradition, ed. George W. Stocking (Madison: University of Wisconsin Press, 1996), 298-336.

Mégret, Frederic. 'From Savages to Unlawful Combatants: A Postcolonial Look at International Law's "Other"', in International Law and Its Others, ed. Anne Orford (Cambridge: Cambridge University Press, 2006), 265-317. 
Meyer, Andrea and Bénédicte Savoy, eds. The Museum is Open. Towards a Transnational History of Museums 1750-1940 (Berlin: De Gruyter, 2014).

Miles, Kate. The Origins of International Investment Law. Empire, Environment and the Safeguarding of Capital (Cambridge: Cambridge University Press, 2013).

Ministre des Colonies. 'Rapport au Président de la République Française, December 23, 1924'. Bulletin de l'Ecole francaise d'Extrême-Orient 26 (1926), 526-527.

Obenaus, Maria. Für die Nation gesichert? Das „Verzeichnis der national wertvollen Kunstwerke": Entstehung, Etablierung und Instrumentalisierung 1919-1945 (Berlin: De Gruyter, 2016).

Obregón, Liliana. 'The Civilized and the Uncivilized', in The Oxford Handbook of the History of International Law, eds. Bardo Fassbender and Anne Peters (Oxford: Oxford University Press, 2012), 917-939.

Office International des Musées. 'Le Projet Définitif Établi en 1939 en Vue de la Conférence Diplomatique'. Art et Archéologie. Recueil de Législation Comparée et de Droit International 1 (1939), 78-87.

O'Keefe, Roger. The Protection of Cultural Property in Armed Conflict (Cambridge: Cambridge University Press, 2006).

Oppenheim, Lassa Francis Lawrence. International Law. A Treatise, Vol. 1 (London: Longmans, Green, and Co., 1905).

Oppenheim, Lassa Francis Lawrence. International Law. A Treatise, Vol. 1 (London: Longmans, Green, and Co., 2nd ed., 1912).

Öszu, Umut. 'Ottoman Empire', in The Oxford Handbook of the History of International Law, eds. Bardo Fassbender and Anne Peters (Oxford: Oxford University Press, 2012), 429-448.

Pauka, Marc. Kultur, Fortschritt und Reziprozität. Die Begriffsgeschichte des zivilisierten Staates im Völkerrecht (Baden-Baden: Nomos, 2012).

Pedersen, Susan. The Guardians. The League of Nations and the Crisis of Empire (Oxford: Oxford University Press, 2015).

Pillet, Antoine. Le Droit de la Guerre (Paris: Arthur Rousseau, 1893).

Pitts, Jennifer. Boundaries of the International. Law and Empire (Cambridge: Harvard University Press, 2018).

Prott, Lyndel V. and Patrick J. O'Keefe. “Cultural Heritage' or 'Cultural Property'?'. International Journal of Cultural Property 1(2) (1992), 307-320.

Rajagopal, Balakrishnan. International Law from Below. Development, Social Movements and Third World Resistance (Cambridge: Cambridge University Press, 2003).

'Recommandations de l'Assemblée de la Société des Nations du 10 Octobre 1932'. Art et Archéologie. Recueil de Législation Comparée et de Droit International 1 (1939), 114 et seq. 
Reimann, Mathias. 'Comparative Law and Private International Law', in The Oxford Handbook of Comparative Law, eds. Mathias Reimann and Reinhard Zimmermann (Oxford: Oxford University Press, 2006), 1363-1396.

Roberts, Anthea. Is International Law International? (Oxford: Oxford University Press, 2017).

Röben, Betsy. Johann Caspar Bluntschli, Francis Lieber und das moderne Völkerrecht 1861-1881 (Baden-Baden: Nomos, 2003).

Roerich, Nicholas. Roerich Banner of Peace (New York: Roerich Museum Press, 1931).

Sandholtz, Wayne. Prohibiting Plunder: How Norms Change (Oxford: Oxford University Press, 2007).

Sarr, Felwine and Bénédicte Savoy. The Restitution of African Cultural Heritage. Toward a New Relational Ethics (2018), available at: http://restitutionreport2018.com/sarr_ savoy_en.pdf (last accessed on 14 September 2020).

Savoy, Bénédicte. Die Provenienz der Kultur. Von der Trauer des Verlusts zum universalen Menschheitserbe (Berlin: Matthes \& Seitz, 2018).

Savoy, Bénédicte. Kunstraub, Napoleons Konfiszierungen in Deutschland und die europäischen Folgen (Vienna: Böhlau Verlag, 2011).

Schayegh, Cyrus and Andrew Arsan, eds. The Routledge Handbook of the History of the Middle East Mandates (Abingdon: Routledge, 2015).

Schindler, Dietrich and Jiři Toman, eds. The Laws of Armed Conflicts. A Collection of Conventions, Resolutions and Other Documents (Leiden: Martinus Nijhoff, 3rd ed. 2004).

Schmoeckel, Mathias. 'The Internationalist as a Scientist and Herald: Lassa Oppenheim'. European Journal of International Law 11(3) (2000), 699-712.

Schwartz, Bill. The White Man's World (Oxford: Oxford University Press, 2011).

Shahabuddin, Mohammad. 'The 'Standard of Civilization' in International Law: Intellectual Perspectives from Pre-war Japan'. Leiden Journal of International Law 32 (1) (2018), 13-32.

Shaw, Malcolm N. International Law (Cambridge: Cambridge University Press, 8th ed. 2017).

Shaw, Wendy. Possessors and Possessed. Museum, Archaeology, and the Visualization of History in the Late Ottoman Empire (Berkeley: University of California Press, 2003).

Spitra, Sebastian M. Die Verwaltung von Kultur im Völkerrecht. Eine postkoloniale Geschichte (Baden-Baden: Nomos, forthcoming 2020).

Steiger, Heinhard. 'Völkerrecht', in Geschichtliche Grundbegriffe, Vol. 7, eds. Otto Brunner, Werner Conze and Reinhart Koselleck (Stuttgart: Klett-Cotta, 1992), 97-140.

Taşdelen, Alper. The Return of Cultural Artefacts. Hard and Soft Law Approaches (Berlin: Springer, 2016). 
Ullmann, Emanuel. Völkerrecht (Tübingen:J. C. B. Mohr, 1908).

Vec, Miloš. 'All's Fair in Love and War or the Limits of the Limitations. Juridification of Warfare and Its Revocation by Military Necessity', in Civility, Barbarism and the Evolution of International Humanitarian Law: Who Do the Laws of War Protect?, ed. Matt Killingsworth (Cambridge: Cambridge University Press, forthcoming).

Verhoeve, Joe. 'Charles de Visscher: Living and Thinking International Law'. European Journal of International Law 11(4) (2000), 887-904.

Vrdoljak, Ana F. International Law, Museums and the Return of Cultural Objects (Cambridge: Cambridge University Press, 2006).

Wheaton, Henry. Elements of International Law, ed. Richard Henry Dana (London: Sampson Low, Son and Co., 8th ed., 1866).

Wussow, Alexander von. Die Erhaltung der Denkmäler in den Kulturstaaten der Gegenwart (Berlin: Carl Heymanns, 1885). 